\title{
Publisher Correction: Ticks parasitised feathered dinosaurs as revealed by Cretaceous amber assemblages
}

\author{
Enrique Peñalver (10) ${ }^{1}$, Antonio Arillo ${ }^{2}$, Xavier Delclòs (10 ${ }^{3}$, David Peris (10 ${ }^{4}$, David A. Grimaldi ${ }^{5}$, \\ Scott R. Anderson (10 ${ }^{6}$, Paul C. Nascimbene ${ }^{5} \&$ Ricardo Pérez-de la Fuente ${ }^{7}$
}

Correction to: Nature Communications https://doi.org/10.1038/s41467-017-01550-z, Article published online 12 December 2017

The originally published version of this Article was updated shortly after publication to add the word 'Ticks' to the title, following its inadvertent removal during the production process. This has now been corrected in both the PDF and HTML versions of the Article.

Published online: 30 January 2018

\begin{abstract}
(c) (i) Open Access This article is licensed under a Creative Commons Attribution 4.0 International License, which permits use, sharing, adaptation, distribution and reproduction in any medium or format, as long as you give appropriate credit to the original author(s) and the source, provide a link to the Creative Commons license, and indicate if changes were made. The images or other third party material in this article are included in the article's Creative Commons license, unless indicated otherwise in a credit line to the material. If material is not included in the article's Creative Commons license and your intended use is not permitted by statutory regulation or exceeds the permitted use, you will need to obtain permission directly from the copyright holder. To view a copy of this license, visit http://creativecommons.org/licenses/by/4.0/.
\end{abstract}

(C) The Author(s) 2018

\footnotetext{
${ }^{1}$ Museo Geominero, Instituto Geológico y Minero de España, 28003 Madrid Spain. ${ }^{2}$ Departamento de Zoología y Antropología Física, Facultad de Biología, Universidad Complutense, 28040 Madrid Spain. ${ }^{3}$ Departament de Dinàmica de la Terra i de I'Oceà and Institut de Recerca de la Biodiversitat (IRBio), Facultat de Ciències de la Terra, Universitat de Barcelona, 08028 Barcelona Spain. ${ }^{4}$ Departament de Ciències Agràries i del Medi Natural, Universitat Jaume I, 12071 Castelló de la Plana Spain. ${ }^{5}$ Division of Invertebrate Zoology, American Museum of Natural History, New York, NY 10021, USA. ${ }^{6}$ Independent Researcher, Moon Township USA. ${ }^{7}$ Oxford University Museum of Natural History, Parks Road, Oxford OX1 3PW, UK. Correspondence and requests for materials should be addressed to E.P. (email: e.penalver@igme.es) or to R.P.-d.I.F. (email: ricardo.perez-de-lafuente@oum.ox.ac.uk)
} 